\title{
ANALISIS PENGARUH ORIENTASI SERAT TERHADAP KEKUATAN IMPAK DAN MODEL PATAHAN KOMPOSIT POLYESTER BERPENGUAT SERAT GAHARU
}

\author{
Yuliyanto $^{1}$, Masdani $^{2}$ \\ ${ }^{1,2}$ Jurusan Teknik Mesin, Politeknik Manufaktur Negeri Bangka Belitung \\ Kawadan Industri Air Kantung Sungailiat Bangka \\ Email: yulianto@polman-babel.ac.id
}

\begin{abstract}
Abstrak
Komposit merupakan sistem yang tersusun melalui pencampuran dua material atau lebih yang berbeda, dalam bentuk dan komposisi. Antara kedua material atau lebih tidak larut satu sama lainnya. Komposit sangat berpengaruh terhadap sifat mekanik. Faktor yang sangat berpengaruh adalah Fraksi serat, panjang serat serta perendaman yang digunakan. Penelitian ini bertujuan melihat pengaruh panjang serat, Perendaman dan perbandingan fraksi volume terhadap sifat mekanik untuk bahan komposit berpenguat serat kulit gaharu. Penelitian ini menggunakan fraksi panjang serat $20 \mathrm{~mm}, 40 \mathrm{~mm}, 60 \mathrm{~mm}$, dengan waktu perendaman 1 jam, 2 jam, 3 jam dengan perbandingan fraksi volume 30\%:70\%, 40\%:60\% dan 50\%:50\% .Bahan yang digunakan serat Kulit Gaharu dengan kadar air 10\%-12\%. Pembuatan komposit menggunakan metode hand lay up. Pengujian yang dilakukan adalah uji Impact Charpy dengan standar pengujian ISO179. Hasil penelitian uji impak akan dianalisa dengan perangkat lunak Design Expert 9. Hasil kekuatan impak terkecil dengan hasil $24.94 \mathrm{kj} / \mathrm{m}^{2}$ dengan parameter dengan panjang serat $3 \mathrm{~mm}$, perendaman serat 3 jam dan persentase serat 30/70\%. Hasil percobaan terbesar dengan dengan panjang serat $4 \mathrm{~mm}$, perendaman serat 2 jam dan persentase serat $40 / 60 \%$. Hasil Kekuatan impaknya $77.112 \mathrm{kj} / \mathrm{m}^{2}$. . Hasil percobaan tersebut memberikan pengaruh terhadap kekuatan impak, dimana perendaman dan persentase memberikan pengaruh yang sangat besar. Ini dikarenakan lamanya perendaman akan mempengaruhi serat sehinga mudah putus dan rapuh. persentase serat memberikan pengaruh yang besar pula disebabkan karena jika serat diatas 10\% dan dibawah $50 \%$ maka nilai uji impak besar pula. Tetapi jika persentase serat diatas $50 \%$ maka nilai uji impak semakin kecil
\end{abstract}

Kata kunci : komposit, serat kulit gaharu, panjang serat,uji impak

\begin{abstract}
Composite is a system composed by mixing two or more different materials in form and composition. Between the two materials or more insoluble to each other. Composites are very influential on mechanical properties. Factors that are very influential are the fiber fraction, fiber length and soaking used. This study aims to see the effect of fiber length, immersion and comparison of volume fractions on mechanical properties for composite materials reinforced aloes skin fibers. This study used a fraction of fiber length of $20 \mathrm{~mm}, 40 \mathrm{~mm}, 60 \mathrm{~mm}$, with a soaking time of 1 hour, 2 hours, 3 hours with a comparison of the volume fraction of 30\%: 70\%, 40\%: 60\% and 50\%: 50\%. Aloes Skin fiber is used with water content of 10\%-12\%. Composite making using the hand lay up method. Tests carried out are the Charpy Impact test with ISO179 testing standards. The results of the impact test study will be analyzed with Design Expert 9. The smallest impact strength results with a result of $24.94 \mathrm{kj} / \mathrm{m} 2$ with parameters with $3 \mathrm{~mm}$ fiber length, 3 hours of fiber immersion and 30/70\% fiber percentage. The biggest experimental results with $4 \mathrm{~mm}$ fiber length, 2 hours fiber immersion and 40/60\% fiber percentage. Results The impact strength is $77.112 \mathrm{kj} /$ $m 2$.. The results of the experiment have an impact on impact strength, where immersion and percentage have a very large influence. This is because the length of the immersion will affect the fiber so that it is easily broken and brittle. percentage of fiber gives a big influence also because if the fiber is above 10\% and below 50\% then the value of the impact test is also great. But if the percentage of fiber is above 50\% then the impact test value gets smaller
\end{abstract}

Keywords: composite, aloes skin fiber, fiber length, impact test

15 Yuliyanto, dkk; Analisis Pengaruh Orientasi Serat Terhadap Kekuatan Impak Dan Model Patahan Komposit Polyester Berpenguat Serat Gaharu 


\section{PENDAHULUAN}

Serat alam merupakan material yang sangat baik sebagai bahan penguat. Serat alam menghasilkan bahan komposit yang ringan, kuat, ramah lingkungan serta ekonomis. Beberapa jenis serat alam seperti Sisal, Flex, Hemp, Jute, Rami, Kelapa, mulai digunakan sebagai bahan penguat untuk komposit polimer. Dengan kemajuan teknologi, saat ini telah banyak produk mengunakan bahan komposit dengan serat alam. Faktor utama yang mendorong dari penggunaan serat alam dalam industri yaitu biaya dan berat. Meskipun demikian kemudahan daur ulang komponen juga merupakan pertimbangan akhir yang semakin meningkat untuk memenuhi persyaratan dari petunjuk untuk umur komponen.

Homogenisasi antara serat dan matrik akan sulit tercapai, dikarenakan terlalu padatnya bahan penguat matrik. Sehingga matrik dan penguat akan sulit tercampur secara homogen yang tentu saja akan mempengaruhi kekuatan dari komposit tersebut. Begitu juga sebaliknya. Sehingga jumlah serat yang hanya $10 \%$ dari jumlah matriks, tidak mampu menahan beban yang lebih besar dan menghasilkan nilai pengujian yang relatif rendah. Waktu perendaman serat juga memberikan pengaruh terhadap kekuatan tarik. Perendaman serat pohon waru pada air laut pH 6 mengakibatkan timbulnya celah antar sub serat dan waktu perendaman menyebabkan jarak antar subcelah semakin tinggi. Perendaman meningkatkan kekuatan Tarik tetapi semakin lama perendaman kekuatan tarik semakin menurun

Pembuatan panel panjat tebing dilakukan dengan menggunakan serat sabut kelapa (cocos nucifera) sebagai serat penguat yang telah dilakukan perendaman dalam selama 2 jam, dilakukan menggunakan metode hand lay up Jika dilihat dari hasil penelitian panel panjat tebing serat sabut kelapa maka kekuatan mekanik panel panjat tebing serat sabut kelapa belum mencapai kekuatan mekanik panel panjat tebing yang telah distandarkan oleh Badan Standarisasi dan Akreditasi Pemanjatan Indonesia (BSAPI). Perlakuan permukaan terhadap sifat kimia pada serat kulit batang melinjo yang berkaitan dengan sifat mekanis serat. Proses dilakukan dengan memberikan perlakuan permukaan pada serat kulit batang melinjo, hasilnya mampu memberikan dampak pada sifat kimia, fisika dan sifat mekanis. Meningkatnya konsentrasi $\mathrm{NaOH}$, mampu menghilangkan lapisan wax, lignin dan impuritas pada permukaan serat.

Komposit serat alam memilki keunggulan dibandingkan dengan serat gelas, komposit serat alam sekarang digunakan karena jumlahnya banyak, ramah lingkungan, mampu terdegradasi secara alami, harganya murah dibandingkan serat gelas. Kelemahan serat alami adalah semakin kecil diameter serat kekuatan tariknya besar, karena rongga pada serat kecil dan ikatan antar molekulnya banyak sehingga kekuatannya kuat. Semakin besar diameter maka kekuatan tariknya kecil, karena rongga pada serat besar dan ikatan molekulnya sedikit sehingga kekuatan tariknya rendah. Semakin bertambahnya fraksi serat E-glass dapat menyebabkan kekuatan mekanik komposit menurun.

Pohon gaharu menghasilkan serat pada bagian kulit pohonnya. Saat ini pemanfaatan serat kulit pohon gaharu terbatas pada pengunaan dan belum diolah menjadi produk teknologi. serat kulit pohon gaharu dulunya dimanfaatkan oleh masyarakat sebagai tali pengikat lada. karena harga tali plastik lebih murah dan mudah didapatkan akibatnya pembuatan tali dari bahan serat kulit pohon gaharu semakin berkurang. Tuntutan teknologi ini disesuaikan juga dengan keadaan alam yang mendukung untuk pemanfaatannya secara langsung. Oleh karena itu, pemanfaatan serat kulit pohon gaharu sebagai penguat bahan komposit dibidang rekayasa merupakan salah satu gagasan yang perlu dikembangkan.

Penelitian dilakukan untuk mendapatkan data kemampuan mekanik berupa kekuatan impak serta bentuk fisik dari serat kulit gaharu menggunakan matriks polyester BQTN 157, dengan variasi fraksi volume, Perendaman dan panjang serat. Harapannya serat ini dapat menjadi pilihan bahan utama dalam pembuatan bermacam produk yang lebih ramah lingkungan serta memiliki kualitas yang baik.

\section{METODE PENELITIAN}

Penelitian dilakukan dengan beberapa tahap. Proses yang digunakan mengikuti pedoman penelitian. langkah awal dimulai dari studi-studi literatur yang didapat dari jurnal ilmiah. internet, handbook, text book, manual book. Selanjutnya datadata studi literature dipelajari dan dijadikan referensi untuk melakukan penelitian. Studi literatur merupakan bagian dari kegiatan mengumpulkan berbagai teori yang mendukung kepada penelitian yang akan dilakukan, dengan tujuan untuk mengidentifikasi konsep, teori dan fakta. Uraian langkah-langkah tersebut dijelaskan pada diagram alir (Gambar 1).

16 Yuliyanto, dkk; Analisis Pengaruh Orientasi Serat Terhadap Kekuatan Impak Dan Model Patahan Komposit Polyester Berpenguat Serat Gaharu 


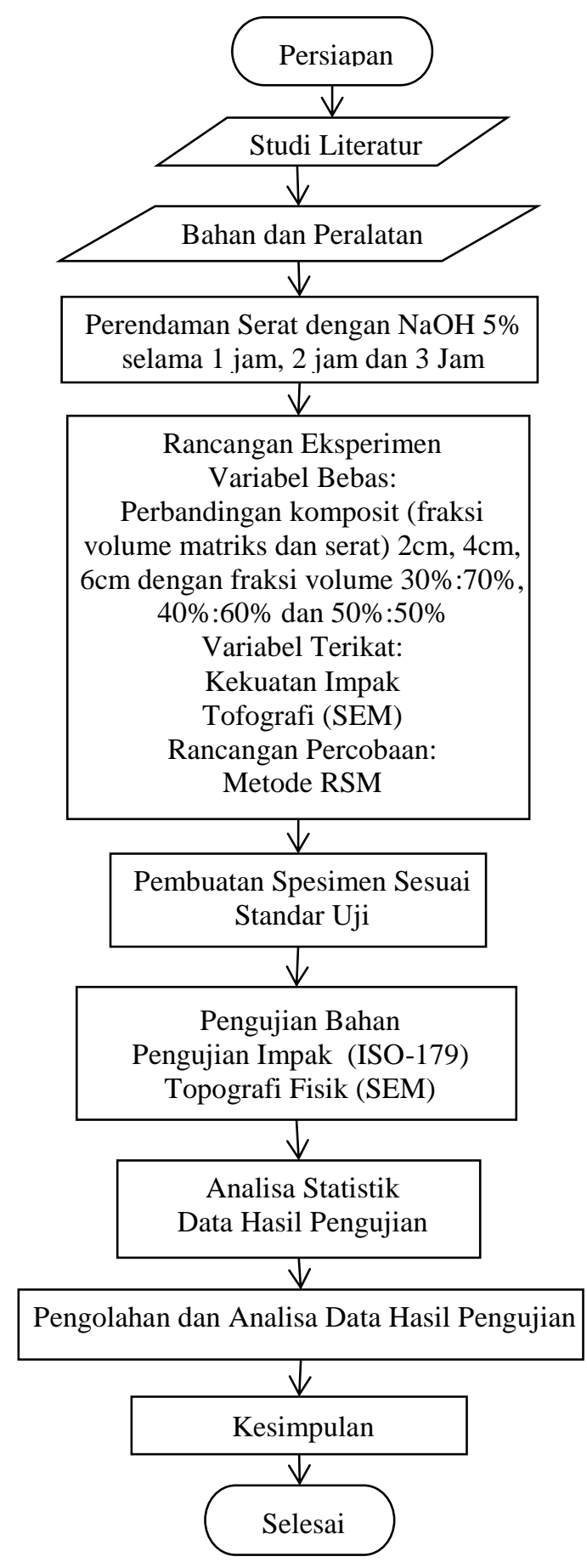

\section{Gambar 1 Diagram Alir Penelitian}

Bahan yang digunakan dalam penelitian ini adalah sebagai berikut: Serat kulit kayu gaharu yang berfungsi sebagai penguat pada komposit. Serat kulit gaharu, Resin Unsaturated Polyester yang berfungsi sebagai matriks dalam komposit dan Katalis yang digunakan adalah Methyle Ethyl Keton Peroxide (MEKPO) berfungsi mempercepat pengerasan pada komposit. Serat kulit gaharu dapat dilihat pada Gambar 2.
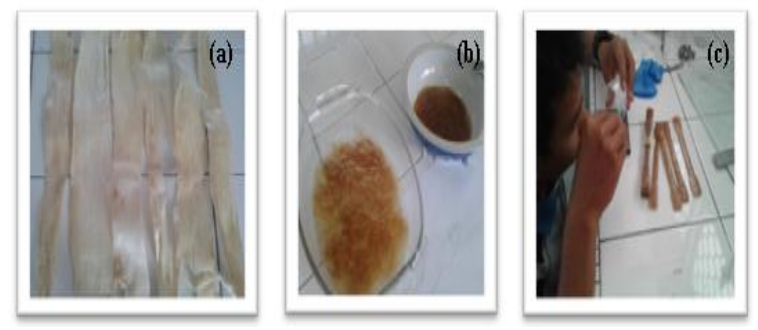

Gambar 2 (a) Serat Kulit Gaharu, (b) Proses Perendaman, (c) Poses pembuatan sample

Alat uji yang digunakan adalah uji Impact Charpy dengan standar pengujian ISO-179 digunakan untuk mendapatkan nilai ketangguhan komposit. Sifat mekanik yang diperoleh yaitu kekuatan impact.. Alat Uji Scanning Electron Microscope (SEM) yang digunakan adalah Inspect S50 buatan FEI Company. Alat ini untuk mengetahui perubahan struktur yang terjadi dari hasil pengujian.

Analisa dilakukan dengan mengunakan metode permukaan respon, dimana akan dilihat pengaruh perendaman dan variabel Bebas Perbandingan komposit (fraksi volume matriks dan serat) dengan panjang serat dan fraksi volume.

\section{HASIL DAN PEMBAHASAN}

Pengujian ini dilakukan untuk mengetahui pengaruh perendaman 1 jam, 2 jam, 3 jam, perbandingan komposit (fraksi volume matriks dan serat) dengan panjang serat $2 \mathrm{~cm}, 4 \mathrm{~cm}, 6 \mathrm{~cm}$ dengan fraksi volume 30\%:70\%, 40\%:60\% dan 50\%:50\%. Keseluruhan parameter pengujian diolah dengan Design expert 9. Dari hasil pengolahan parameter terbentuk 20 jumlah sampel deng 6 kali pengulangan.

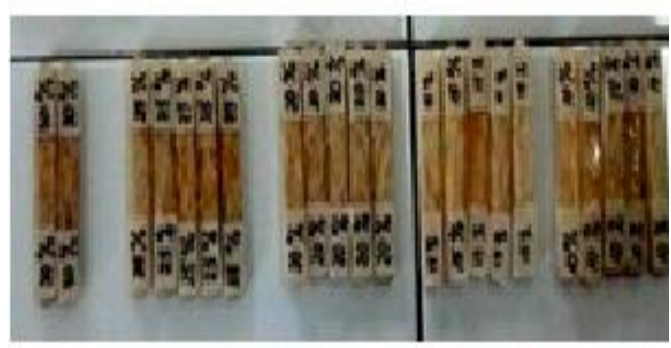

Gambar 3 Sample Uji Impak

Pengolahan dengan design expert 9 dapat dilhat pada gambar 4 dibawah ini. 


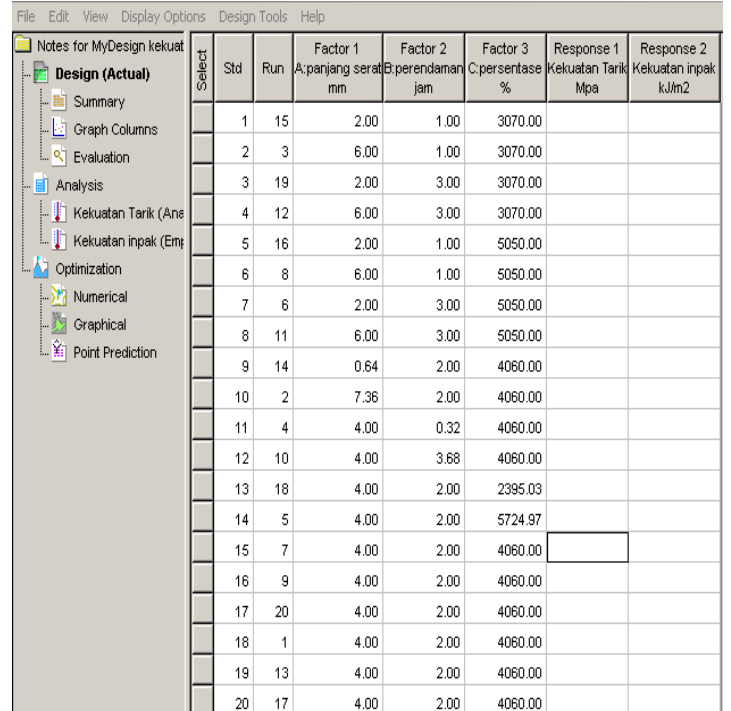

Gambar 4 Data Design Expert 9

Setelah proses pembuatan sampel maka dilakukan uji mekanik yaitu uji impak dengan mengacu pada standar ISO-179. Hasil pengujian impak yang didapatkan ditabulasikan pada Tabel 1.

Tabel 1 Hasil Pengujian Impak

\begin{tabular}{ccccc}
\hline Run & $\begin{array}{c}\text { Level 1 } \\
\text { Panjang Serat }\end{array}$ & $\begin{array}{c}\text { Level 2 } \\
\text { Perendaman }\end{array}$ & $\begin{array}{c}\text { Level 3 } \\
\text { Persentase } \\
\text { serat }\end{array}$ & $\begin{array}{c}\text { Response l } \\
\text { Kekuatan } \\
\text { Immak }\end{array}$ \\
\cline { 2 - 5 } kuj/m2 \\
\hline 1 & 2 & 1 & 3070 & 36.57 \\
2 & 6 & 1 & 3070 & 52.224 \\
3 & 2 & 3 & 3070 & 24.945 \\
4 & 6 & 3 & 3070 & 30.72 \\
5 & 2 & 1 & 5050 & 49.224 \\
6 & 6 & 1 & 5050 & 50.054 \\
7 & 2 & 3 & 5050 & 52.945 \\
8 & 6 & 3 & 5050 & 46.945 \\
9 & 0.64 & 2 & 4060 & 53.224 \\
10 & 7.36 & 2 & 4060 & 55.804 \\
11 & 4 & 0.32 & 4060 & 49.007 \\
12 & 4 & 3.68 & 4060 & 33.68 \\
13 & 4 & 2 & 2395.03 & 30.72 \\
14 & 4 & 2 & 5724.97 & 36.67 \\
15 & 4 & 2 & 4060 & 64.054 \\
16 & 4 & 2 & 4060 & 66.054 \\
17 & 4 & 2 & 4060 & 77.112 \\
18 & 4 & 2 & 4060 & 66.054 \\
19 & 4 & 2 & 4060 & 62.596 \\
20 & 4 & 2 & 4060 & 64.054 \\
\hline
\end{tabular}

Berdasarkan hasil pengujian impak terhadap sampel serat gaharu didapatlah data dengan nilai tertinggi adalah pada sampel dengan no 17. Dimana hasil uji impak adalah $77.112 \mathrm{kj} / \mathrm{m}^{2}$. Sedangkan nilai terendah terdapat pada sampel dengan no 3 yaitu sebesar $24.94 \mathrm{kj} / \mathrm{m}^{2}$.

Dari hasil pengolahan data kemudian dilakukan Analisis Varian (ANOVA) untuk memastikan atau menyelidiki hubungan antara variabel respons dengan 1 atau beberapa variabel predictor. Dari hasil Analisi Varian didapat data seperti Tabel 2 berikut ini.

Tabel 2 ANOVA untuk Respon Kekuatan Impak $\left(\mathbf{k j} / \mathbf{m}^{2}\right)$

\begin{tabular}{|c|c|c|c|c|c|}
\hline \multicolumn{2}{|l|}{ Responsi 2} & \multicolumn{4}{|c|}{ Kekuatan inpak } \\
\hline \multicolumn{3}{|c|}{ Transform Natural Io Constant: } & 0 & & \\
\hline \multicolumn{6}{|c|}{ ANOVA for Response Surface Quadratic Model } \\
\hline \multicolumn{6}{|c|}{ Analysis of variance table [Partial sum of squares - Type III] } \\
\hline & Sum of & & Mean & $\mathrm{F}$ & p-value \\
\hline Source & Squares & df & Square & Value & Prob $>F$ \\
\hline Model & 1.73 & 9 & 0.19 & \multicolumn{2}{|c|}{$21.69<0.0001$ significant } \\
\hline A-panjan & 0.021 & 1 & 0.021 & 2.42 & 0.1511 \\
\hline B-perenc & 0.17 & 1 & 0.17 & 19.48 & 0.0013 \\
\hline C-persen & 0.22 & 1 & 0.22 & 24.72 & 0.0006 \\
\hline $\mathrm{AB}$ & 0.01 & 1 & 0.01 & 1.15 & 0.3094 \\
\hline $\mathrm{AC}$ & 0.056 & 1 & 0.056 & 6.3 & 0.0309 \\
\hline $\mathrm{BC}$ & 0.11 & 1 & 0.11 & 12 & 0.0061 \\
\hline$A^{n} 2$ & 0.064 & 1 & 0.064 & 7.24 & 0.0227 \\
\hline $\mathrm{B}^{\wedge} 2$ & 0.42 & 1 & 0.42 & \multicolumn{2}{|c|}{$47.33<0.0001$} \\
\hline $\mathrm{C}^{\wedge} 2$ & 0.82 & 1 & 0.82 & \multicolumn{2}{|c|}{$92.23<0.0001$} \\
\hline Residual & 0.089 & 10 & $8.86 \mathrm{E}-03$ & \multirow{4}{*}{2.11} & \multirow{3}{*}{0.216 not significant } \\
\hline Lack of Fit & 0.06 & 5 & 0.012 & & \\
\hline Pure Error & 0.028 & 5 & 5.70E-03 & & \\
\hline Cor Total & 1.82 & 19 & & & \\
\hline
\end{tabular}

Berdasarkan Tabel 2 terlihat nilai $\mathrm{F}$ hitung $F_{\text {Model }}=21,69$ yang didapat pada tingkat signifikan sebesar 0,01 atau $1 \%$ dan nilai p $(0,0001)$ memberikan nilai signifikan terhadap model yang ada. Sedangkan Lack of Fit yang terjadi sebesar 0,012 dan tidak memberikan pengaruh (not signifikan) sehingga persamaan regresi mode matematika dengan bentuk quadratik yang digunakan dapat diterima.

Jika kita liat sebaran yang terjadi pada model grafik, maka nilai uji impak sangat merata. Rata-rata 6 kali pengulangan masih memiliki nilai yang stabil. Ini dapat dilihat pada gambar 5.

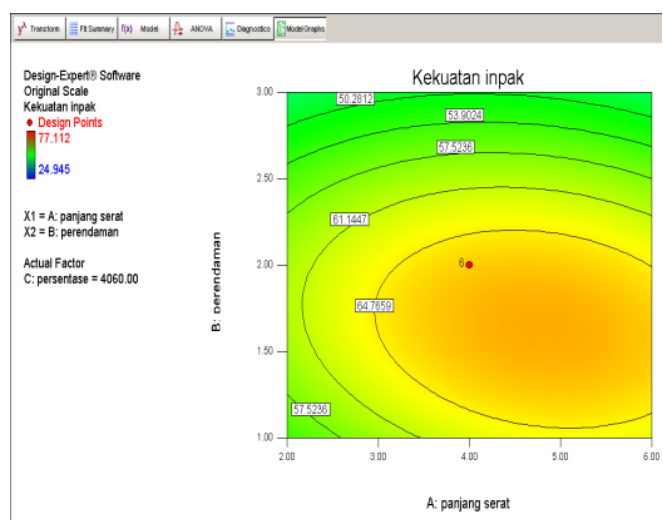

Gambar 5 Penyebaran Hasil Uji Impak

Jika dilihat dari Gambar 3 dimensi menggunakan Design Expert 9 maka didapat gambar permukaan respon model Quadratik antara masingmasing variable bebas (Gambar 6).

18 Yuliyanto, dkk; Analisis Pengaruh Orientasi Serat Terhadap Kekuatan Impak Dan Model Patahan Komposit Polyester Berpenguat Serat Gaharu 


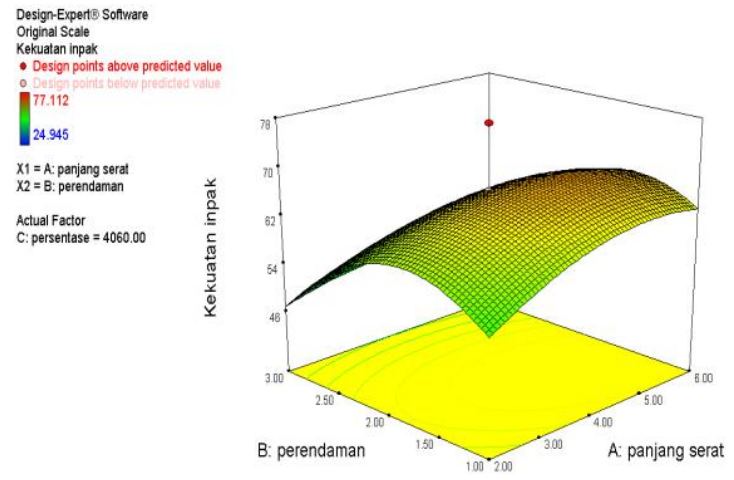

Gambar 6 Permukaan Respon Model Quadratik Kekuatan Impak vs Perendaman dan Panjang serat

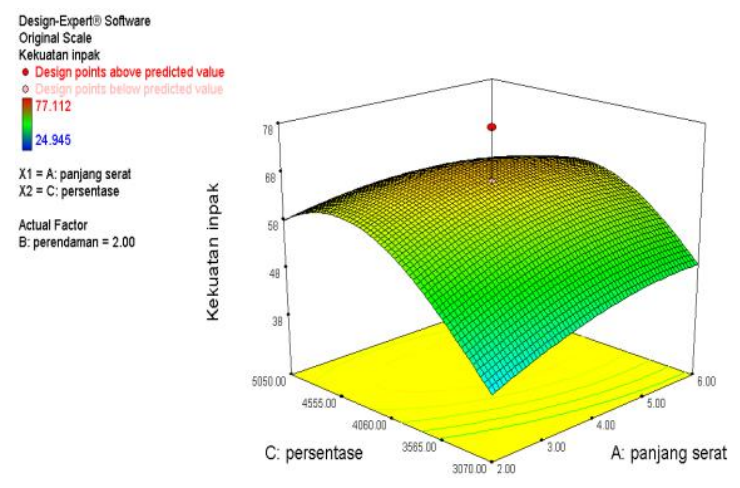

Gambar 7 Permukaan Respon Model Quadratik Kekuatan Impak vs persentase dan Panjang serat

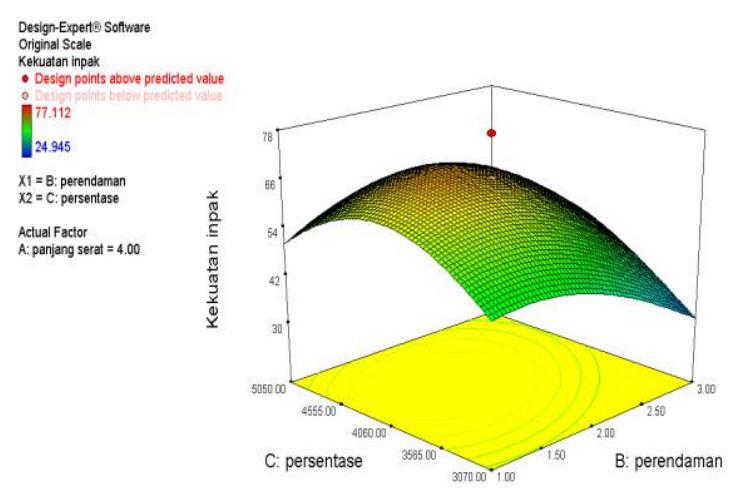

Gambar 8 Permukaan Respon Model Quadratik Kekuatan Impak vs Perendaman dan Persentase

Permukaan respon grafik 3D (Gambar 8) untuk kekuatan Impak diatas dapat dilihat bahwa, kenaikan nilai perendaman sangat mempengaruhi hasil kekuatan Tarik. Dimana semakin lama waktu perendaman maka hasil kekuatan impak semakin menurun. Panjang serat memberikan pengaruh yang siknifikan terhadap kekuatan impak. Ini dapat dilihat pada kenaikan grafik dari panjang serat $2 \mathrm{~mm}$ sampai $5 \mathrm{~mm}$.

Pada gambar 6 dan gambar 7 pengaruh persentase serat sangat siqnifikan dimana semakin tinggi persentase serat maka nilai kekuatan impak semakin besar tetapi terjadi penurunan kekuatan impak di 50/50 \%. Sedangkan pengaruh panjang serat tidak berpengaruh besar. Ini dapat disimpulkan bahwa Perendaman dan persentase serat memberikan dampak yang besar terhadap perubahan nilai kekuatan impak. Sedangkan pengaruh Panjang serat yang digunakan menunjukan kenaikan nilai kekuatan impak. Secara keseluruhan dapat diartikan bahwa semakin banyak serat maka nilai kekuatan tariknya semakin kecil.

Scanning Electron Microscope (SEM) dilakukan menggunakan Inspect S50. Pengujian SEM dilakukan sebanyak 2(dua) kali dengan pembesaran 200x dan 500x. Tujuan pengujian ini adalah untuk melihat hasil permukaan patahan uji impak yang telah dilakukan dengan parameter yang berbeda. Hasil pengujian SEM dapat dilihat pada Gambar 8.

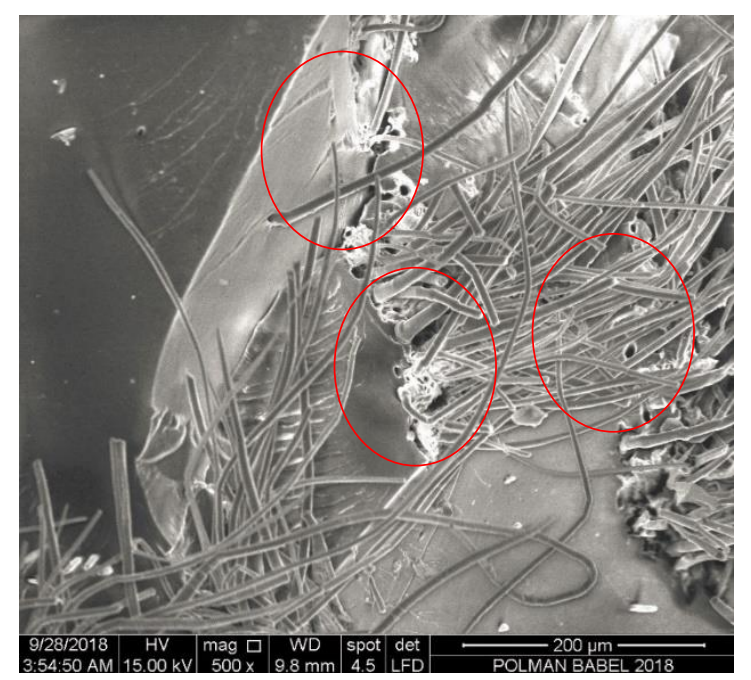

Gambar 9 Gambar percobaan kekuatan impak terkecil pembesaran $500 \mathrm{x}$

Gambar 9 adalah percobaan ke 3 dengan panjang serat $3 \mathrm{~mm}$, perendaman serat 3 jam dan persentase serat $30 / 70 \%$. Analisis hasil SEM menunjukan sebaran serat yang tidak merata dan ada beberapa serat yang tercabut ( lingkaran merah) bukan terputus akibat pengujian. Hal ini disebabkan penyatuan serat dengan resin tidak homogen atau tidak sempurna yang menyebabkan hasil uji impak menunjukan nilai uji impak kecil. 


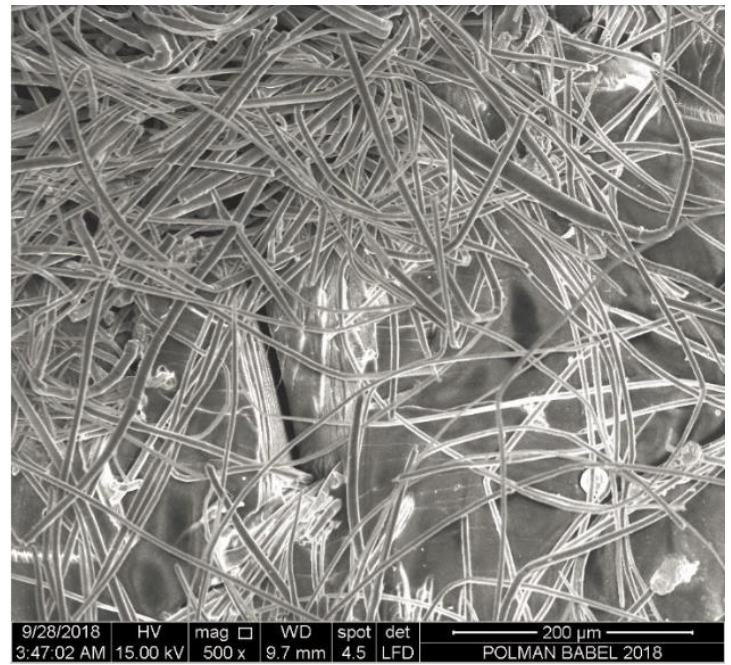

Gambar 10 Gambar percobaan kekuatan impak terkecil pembesaran $500 \mathrm{x}$

Gambar 10 adalah percobaan ke 17 dengan panjang serat $4 \mathrm{~mm}$, perendaman serat 2 jam dan persentase serat $40 / 60 \%$. Hasil Kekuatan impaknya $77.112 \mathrm{kj} / \mathrm{m}^{2}$. Analisis hasil SEM menunjukan sebaran serat yang merata dan tidak ada serat yang tercabut akibat pengujian. Hal ini menunjukan penyatuan serat dengan resin homogen atau sempurna yang menyebabkan hasil uji impak menunjukan nilai yang besar.

\section{KESIMPULAN}

Berdasarkan hasil percobaan dan pembahasan yang dilakukan, dapat diambil beberapa kesimpulan:

1. Hasil kekuatan impak terkecil terdapat pada percobaan ke 3 dengan hasil $24.94 \mathrm{kj} / \mathrm{m}^{2}$ dengan parameter panjang serat $3 \mathrm{~mm}$, Perendaman 3 Jam dan Persentase serat 30\%/70\%. Hasil percobaan terbesar terdapat pada percobaan ke 17 dengan hasil hasil $77.112 \mathrm{kj} / \mathrm{m}^{2}$ dengan parameter panjang serat $4 \mathrm{~mm}$, Perendaman 2 Jam dan Persentase serat $40 \% / 60 \%$.

2. Hasil percobaan dengan ketiga variable bebas memberikan pengaruh terhadap kekuatan impak, dimana perendaman memberikan pengaruh yang sangat besar. Ini dikarenakan lamanya perendaman akan mempengaruhi serat sehinga mudah putus dan rapuh. Sedangkan persentase serat memberikan pengaruh yang besar pula disebabkan karena jika serat diatas $10 \%$ dan dibawah $50 \%$ maka nilai uji impak besar pula. Tetapi jika persentase serat diatas $50 \%$ maka nilai uji impak semakin kecil. Hal ini disebabkan ketika resin dimasukan kecetakan maka serat yang terlalu banyak akan menutupi pergerakan resin. Sehingga penyatuan serat dengan resin tidak homogeny atau merata.

\section{DAFTAR PUSTAKA}

[1] Brett, C.S. \& Adas, R. (2009). Industrial Fibres: Recent and Current Developments. Proceedings of the Symposium on Natural Fibres, 71-82.

[2] Chandrabakty, S., (2014). Fourrier Transform Infra-Red (Ft-Ir) Spectroscopy Dan Kekuatan Tarik Serat Kulit Batang Melinjo Menggunakan Modifikasi Distribusi Weibull. Jurnal Mekanikal, Vol. 5 No, 1, .434 - 442.

[3] Fajri, R. H., Tarkono \& Sugiyanto (2013). Studi Sifat Mekanik Komposit Serat Sansevieria Cylindrica Dengan Variasi Fraksi Volume. Jurnal Fema, Vol. 1, No. 2, 85-93

[4] Mahmuda, E. (2013). Pengaruh Panjang Serat Terhadap Kekuatan Tarik Komposit Berpenguat Serat Ijuk dengan Matrik Epoxy. Journal Eng Unila, Vol. 1 No.3, 79-84.

[5] Mohamad Yuzdhie Ghozali, M.Y., Harini Sosiati, H \& Budiyantoro, C. (2017). Karakterisasi Sifat Tarik Komposit Laminat Hibrid Kenaf-E-Glass/Polyethylene (Pe). Jurnal Material dan Proses Manufaktur - Vol.1, No.1, 31-34

[6] Munandar, I. (2013). Kekuatan Tarik Serat Ijuk (Arenga Pinnata Merr). Journal Eng Unila, Vol. 1, No. 3, 52-58.

[7] Prasetyo, A., Purwanto, H., \& Respati, S. M. B. (2016). Pengaruh Waktu Perendaman Serat Kulit Pohon Waru (Hibiscus tiliaceus) Pada Air Laut Terhadap Struktur Mikro dan Kekuatan Tarik. Jurnal Momentum Vol. 12, No. 2, 42-47.

[8] Suhdi, Mardhika, S., \& Rosa, F. (2016). Analisa Kekuatan Mekanik Komposit Serat Sabut Kelapa (Cocos Nucifera) Untuk Pembuatan Panel Panjat Tebing Sesuai Standar Bsapi, Machine; Jurnal Teknik Mesin, Vol. 2 No. 1, 29-35 